\title{
Heart rate variability in patients with decompensated liver cirrhosis - a pilot study
}

\author{
Zmienność rytmu serca u chorych z niewyrównaną marskością wątroby - \\ badanie pilotażowe
}

\author{
Jolanta Białkowska1 , Adam Rafał Poliwczak², Maciej Jabłkowski', Marzena Koziróg², Katarzyna Dworniak², \\ Joanna Woźny', Marlena Broncel ${ }^{2}$ \\ 1Department of Infectious and Liver Diseases, Medical University of Lodz, Poland \\ 2Department of Internal Diseases and Clinical Pharmacology, Medical University of Lodz, Poland
}

Prz Gastroenterol 2012; 7 (3): 149-155

DOI: $10.5114 / p g .2012 .29881$

Key words: liver cirrhosis, heart rate variability.

Słowa kluczowe: marskość wątroby, zmienność rytmu serca.

\begin{abstract}
Address for correspondence: Adam Rafał Poliwczak MD, PhD, Department of Internal Diseases and Clinical Pharmacology, Medical University of Lodz, 1/5 Kniaziewicza, 91-347 Lodz, Poland, phone: +48 4265110 59, fax: +48 4265110 59, e-mail: polczak@mp.pl, adam.poliwczak@umed.lodz.pl
\end{abstract}

\begin{abstract}
Introduction: Cirrhosis is associated with many disorders of the cardiovascular system defined "cirrhotic cardiomyopathy". They concern, among others autonomic imbalance. One of the ways to evaluate these disorders is to study the heart rate variability (HRV). Abnormal HRV values occur in hypertension, ischemic heart disease, post myocardial infarction and heart failure. Are one of the prognostic factors.

Aim: Evaluation of parameters of HRV in 24-hour Holter monitoring in patients with decompensated cirrhosis.

Material and methods: The study included 18 patients with decompensated cirrhosis and the control group consisted of 16 healthy subjects. Enrolled were performed 24-hour Holter ECG. Heart rate variability parameters, were estimated during whole recording period, separately for night resting and morning activity hours.

Results: There have been significant differences in almost all, both time and frequency HRV parameters between the two groups for follow-up clock. Similar results were obtained by comparing the HRV separately for the night and morning with a control group. The control group achieved statistically significant differences between all the time parameters of HRV at night compared with morning. Frequency parameters showed no significant differences. In patients with cirrhosis demonstrated such differences for the average time NN, SDNN, SDANN, Tr-I, Tinn and ULF. In a 24-hour observation of HRV parameters did not differ significantly depending on the grade in Child-Pugh classification.

Conclusions: Patients with decompensated cirrhosis showed significantly lower HRV parameters than healthy volunteers. In addition, disturbances of circadian distribution showed
\end{abstract}

\section{Streszczenie}

Wstęp: Marskość wątroby wiąże się z wieloma zaburzeniami układu sercowo-naczyniowego określanymi jako cirrhotic cardiomyopathy. Dotyczą one m.in. układu autonomicznego i równowagi współczulno-przywspółczulnej. Jednym ze sposobów oceny tych zaburzeń jest badanie dobowej zmienności rytmu serca (heart rate variability - HRV). Nieprawidłowe wartości HRV występują w nadciśnieniu tętniczym, chorobie niedokrwiennej serca, po przebytym zawale i niewydolności serca. Stanowią jeden z czynników rokowniczych.

Cel: Ocena parametrów HRV w 24-godzinnym badaniu elektrokardiograficznym (EKG) metodą Holtera u osób z niewyrównaną (zdekompensowaną) marskością wątroby.

Materiał i metody: Do badania włączono 18 chorych z niewyrównaną (zdekompensowaną) marskością wątroby. Grupę kontrolną stanowito 16 zdrowych ochotników. Zakwalifikowanym pacjentom wykonano 24-godzinne EKG metodą Holtera. Parametry HRV szacowano dla obserwacji całodobowej oraz dla godzin nocnych (24.00-4.00) i porannych (8.00-12.00). Wyniki: Odnotowano statystycznie istotne różnice $\mathrm{w}$ prawie wszystkich, zarówno czasowych, jak i częstotliwościowych, parametrach HRV pomiędzy badanymi grupami dla obserwacji całodobowej. Podobne wyniki uzyskano, porównując odrębnie HRV dla godzin nocnych i porannych z grupą kontrolną. U osób $z$ grupy kontrolnej stwierdzono znamienne statystycznie różnice pomiędzy wszystkimi parametrami czasowymi HRV z godzin nocnych $w$ porównaniu $z$ godzinami porannymi. Parametry częstotliwościowe nie wykazywały znamiennych różnic. U osób z marskością wątroby różnice takie wykazano dla średniego czasu NN, SDNN, SDANN, Tr-I, TINN oraz ULF. W 24-godzinnej obserwacji parametry HRV nie różnity się znamiennie w zależności od stopnia w skali Childa-Pugha. 
these parameters. Disorders of HRV did not correlate with the severity of liver cirrhosis.

\section{Introduction}

Liver cirrhosis is associated with a number of systemic disturbances including cardiovascular disorders called cirrhotic cardiomyopathy [1-4]. Haemodynamic, electric and regulatory mechanisms are affected. There is evidence on development of autonomic nervous system disorders resulting in sympathetic-parasympathetic imbalance, disturbed autoregulation of brain flow and peripheral vessel reactivity $[5,6]$. A non-invasive tool for evaluation of autonomic nervous system function in cardiovascular diseases is estimation of parameters of heart rate variability (HRV). The HRV is used as a mortality predictor in patients with ischaemic heart disease (IHD), after myocardial infarction (MI), arterial hypertension (HA), and heart failure (HF) [7-11]. A few studies have proved that abnormalities in HRV parameters are observed in liver cirrhosis [12-14]. Independently of the aetiology of liver cirrhosis, reduction in HRV is noted. Reduction in HRV may correlate with progression of liver cirrhosis, vascular changes and systemic abnormalities including hepatic encephalopathy.

\section{Aim}

The aim of our study was to evaluate HRV parameters in patients with decompensation of liver cirrhosis. Abnormalities in HRV parameters that are associated with autonomic nervous system disorder were correlated with cirrhotic liver severity evaluated according to the Child-Pugh classification at discharge from hospital. We also compared HRV parameters in morning activity hours and night resting hours to assess presence of a circadian rhythm.

\section{Material and methods}

The study comprised 18 patients (men: 13, women: 5) selected from 32 patients admitted to the Department of Infectious and Liver Diseases because of decompensated liver cirrhosis (ascites and/or peripheral oedema; bilirubin > $1 \mathrm{mg} / \mathrm{dl}$; albumin < $3.5 \mathrm{~g} / \mathrm{dl}$; encephalopathy $\geq 1$ score; INR > 1.4; symptoms of haemorrhagic diathesis; dyspnoea) between 01.01.2009 and 01.06.2009 and 16 controls. No significant differences were observed in age (52 \pm 10.73 years compared to $52 \pm 14.24$ years, $p=0.876)$, percentage of women $(n=5$ [27.8\%] compared to $n=5$ [31.25\%], $p=0.673)$, or body mass index (BMI) $\left(25.85 \pm 4.26\right.$ vs. $25.6 \pm 2.99 \mathrm{~kg} / \mathrm{m}^{2}$,
Wnioski: U pacjentów z niewyrównaną marskością wątroby występowały znamiennie mniejsze wartości parametrów zmienności rytmu niż u zdrowych ochotników oraz zaburzenia dobowego rozkładu tych parametrów. Zaburzenia HRV nie korelowały z zaawansowaniem marskości wątroby.

$p=0.743$ ) between the study group and control group all $p>0.05$. Exclusion criteria were previous diagnosis of ischemic heart disease, neoplastic diseases including hepatocellular cancer, NYHA class III or IV, alcoholic cardiomyopathy, uncontrolled severe arterial hypertension, renal failure, diabetes mellitus, autoimmunological diseases, nicotine addiction or gastrointestinal haemorrhage during the last 2 months. Diuretics were not given on the day of Holter monitoring and $\beta$-blockers or other drugs known to influence autonomic function were withheld for 5 days before Holter monitoring. The control group comprised 16 volunteers matched for age and sex not treated for liver diseases or for any diseases that excluded patients from the study. On admission medical history was taken, patients were examined; blood samples for laboratory tests were taken; echocardiography and 12-lead ECG were performed. Patients who met the inclusion criteria underwent ECG Holter monitoring. Diagnosis of liver cirrhosis was confirmed by physical examination, laboratory tests, ultrasonography and, if needed, liver biopsy. Among study participants 10 had alcoholic liver cirrhosis, 3 patients had liver cirrhosis related to hepatitis B infection, 3 patients had liver cirrhosis related to hepatitis $C$ infection and 2 patients had idiopathic liver cirrhosis. During hospitalization typical treatment was administered including spironolactone, loop diuretics and propranolol. Loop diuretics and propranolol were administered after ECG Holter monitoring as these drugs may affect the autonomic nervous system. For this reason patients who received loop diuretics and propranolol before admission to the hospital were excluded from the study. The study was performed in agreement with the ethical guidelines of the 1975 Declaration of Helsinki and was approved by the local Bioethics Committee.

\section{Holter ECG monitoring}

Twenty-four-hour ECG was monitored using an Aspect 702 recorder (Aspel Zabierzów, Poland). Data were analysed by an automatic computer system - HolCARD 24W (Aspel Zabierzów, Poland). Automatic detection of QRS complexes was performed. The time and frequency domain of HRV was calculated. Results of these analyses were verified by a cardiologist experienced in 24-hour ECG records. Satisfactory Holter ECG records were obtained from all cirrhotic patients. 


\section{Heart rate variability analysis}

Heart rate variability was analysed and then assessed according to ESC guidelines [7]. Analysis was performed by the fast Fourier transformation test. Heart rate variability parameters were estimated during the whole 24-hour Holter recording period, separately for night resting hours (between 24.00 and 4.00 a.m.) and morning activity hours (between 8.00 and 12.00 a.m.). Heart rate variability was analysed as to time and frequency domain parameters. The following parameters of HRV in the time domain were estimated:

- mean duration of NN (RR) intervals [ms],

- SDNN - standard deviation of NN intervals [ms],

- SDANN - standard deviation of the averages of NN intervals in all 5-minute segments of the entire recording [ms],

- SDNNI - SDNN index - mean of the SD of all NN intervals for all five-minute segments [ms],

- r-MSSD - root mean square successive differences [ms],

- p50NN - percentage of differences between adjacent $\mathrm{NN}$ intervals that are greater than $50 \mathrm{~ms}$ [\%],

- Trl - HRV triangular index - the number of all NN intervals divided by the maximum of the density distribution,

- TINN - the triangular interpolation of the NN interval histogram is the baseline width of the distribution measured as the base of a triangle approximating the NN interval distribution.

Heart rate variability parameters in the frequency domain used in the current study (TP, HF, LF, VLF, ULF, NHF, NLF, LF/HF ratio) were defined as follows:

- TP - total power of frequency domain $\left[\mathrm{ms}^{2}\right]$,

- $\mathrm{HF}$ - high frequency domain [ms²] $(0.15-0.4 \mathrm{~Hz})$,

- LF - low frequency domain [ms $\left.{ }^{2}\right](0.04-0.15 \mathrm{~Hz})$,

- VLF - very low frequency domain $\left[\mathrm{ms}^{2}\right](0.003-0.04 \mathrm{~Hz})$

- ULF - ultra low frequency domain $\left[\mathrm{ms}^{2}\right](<0.003 \mathrm{~Hz})$,

- NHF - normalized HF power,

- NLF - normalized LF power,

- LF/HF - LF/HF ratio.

Among time domain parameters SDANN is considered to be the most appropriate to estimate sympathetic nervous system activity, and p50NN and r-MSSD are considered to be the most appropriate to estimate parasympathetic nervous system activity [7]. Such a clear correlation is not estimated for frequency domain parameters. However, there are some data indicating that $\mathrm{HF}$ is associated with vagus nerve function, LF is correlated with both sympathetic and parasympathetic nervous system, whereas LF/HF ratio estimates sympathetic/parasympathetic balance $[5,13]$.

\section{Statistical analysis}

Statistical analysis was performed using Statistica 8 PL (StatSoft Inc.). Normality of distribution was assessed by the Shapiro-Wilk W test. Continuous variables were non-normally distributed. We used ANOVA rank KruskalWallis test, nonparametric Mann-Whitney and Wilcoxon test. Statistical significance was set at $p<0.05$. Results are presented as mean and standard deviation.

\section{Results}

Significant differences were noted for almost all HRV parameters in the time and frequency domain estimated for the whole 24-hour period between the study and control group as compared in Tables I-III. Significant differences were not found only for HR max, NHF, NLF and LF/HF ratio. The same results were found when HRV parameters were compared separately for morning activity hours and night resting hours. Significant differences $(p<0.001)$ were observed for all parameters excluding NHF, NLF and LH/HF ratio. When we compared HRV parameters between morning activity hours and

Table I. Comparison of HRV parameters in time and frequency domain between study and control group in 24-hour period

Tabela I. Porównanie czasowych i częstotliwosciowych parametrów HRV pomiędzy grupa badana a kontrolna $w$ zapisie 24-godzinnym

\begin{tabular}{lcc} 
Variable & $\begin{array}{c}\text { Cirrhosis } \\
(n=18)\end{array}$ & $\begin{array}{c}\text { Control } \\
(n=16)\end{array}$ \\
\hline Max HR [beats/min] & $125.18 \pm 18.7$ & $115.56 \pm 11.8$ \\
\hline Min HR [beats/min] & $61.82 \pm 10.6$ & $48.30 \pm 4.0^{a}$ \\
\hline Mean HR [beats/min] & $88.06 \pm 13.9$ & $76.00 \pm 6.9^{\mathrm{b}}$ \\
\hline Mean NN [ms] & $687.40 \pm 102.0$ & $866.38 \pm 107.5^{\mathrm{a}}$ \\
\hline SDNN [ms] & $67.07 \pm 27.2$ & $149.69 \pm 32.5^{\mathrm{a}}$ \\
\hline SDNN-ix [ms] & $21.87 \pm 6.9$ & $53.06 \pm 20.5^{\mathrm{a}}$ \\
\hline SDANN [ms] & $61.93 \pm 24.0$ & $131.44 \pm 26.6^{\mathrm{a}}$ \\
\hline r-MSSD [ms] & $15.67 \pm 9.2$ & $44.50 \pm 33.1^{\mathrm{a}}$ \\
\hline p5ONN [\%] & $1.83 \pm 2.7$ & $12.93 \pm 13.2^{\mathrm{a}}$ \\
\hline Trl & $33.80 \pm 13.7$ & $80.88 \pm 25.5^{\mathrm{a}}$ \\
\hline TINN & $277.73 \pm 150.0$ & $740.81 \pm 235.2^{\mathrm{a}}$ \\
\hline TP [ms $\left.{ }^{2}\right]$ & $5278.87 \pm 1676.3$ & $13791.94 \pm 5969.5^{\mathrm{a}}$ \\
\hline HF [ms $\left.{ }^{2}\right]$ & $1281.20 \pm 569.4$ & $4076.00 \pm 2644.7^{\mathrm{a}}$ \\
\hline LF [ms $\left.{ }^{2}\right]$ & $1067.33 \pm 490.6$ & $3519.5 \pm 1647.36626^{\mathrm{a}}$ \\
\hline VLF [ms $\left.{ }^{2}\right]$ & $1474.90 \pm 584.4$ & $3539.13 \pm 1096.2^{\mathrm{a}}$ \\
\hline ULF [ms $\left.{ }^{2}\right]$ & $479.67 \pm 202.5$ & $964.94 \pm 238.8^{\mathrm{a}}$ \\
\hline NHF & $0.90 \pm 0.3$ & $42.14 \pm 5.3$ \\
\hline NLF & $32.85 .31 \pm 8.4$ \\
\hline LF/HF & $0.96 \pm 0.3$ \\
\hline
\end{tabular}

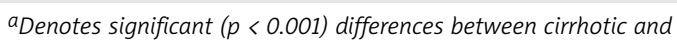
control group; $b$ denotes significant $(p<0.01)$ differences between cirrhotic and control group 
Table II. Comparison of HRV parameters in time and frequency domain between study and control group in 4-hour-long periods (morning activity hours 08.00-12.00; night resting hours 00.00-04.00)

Tabela II. Porównanie czasowych i częstotliwościowych parametrów HRV pomiędzy grupa badana a kontrolna w 4-godzinnych przedziałach czasu (godziny porannej aktywności 8.00-12.00; godziny snu nocnego $0.00-4.00)$

\begin{tabular}{lcccc} 
Variable & \multicolumn{2}{c}{ Morning activity hours } & \multicolumn{2}{c}{ Night resting hours } \\
\cline { 2 - 5 } & Cirrhosis $(n=18)$ & Control $(n=16)$ & Cirrhosis $(n=18)$ & Control $(n=16)$ \\
\hline Mean NN [ms] & $680.47 \pm 108.9$ & $832.63 \pm 106.9^{a}$ & $736.20 \pm 132.0$ & $1030.50 \pm 110.7^{\mathrm{a}}$ \\
\hline SDNN [ms] & $57.60 \pm 25.0$ & $128.88 \pm 43.9^{\mathrm{a}}$ & $44.00 \pm 15.4$ & $94.63 \pm 37.0^{\mathrm{a}}$ \\
\hline SDNN-ix [ms] & $21.40 \pm 8.3$ & $53.13 \pm 23.6^{\mathrm{a}}$ & $23.20 \pm 7.9$ & $63.5 \pm 21.6^{\mathrm{a}}$ \\
\hline SDANN [ms] & $52.73 \pm 22.0$ & $109.25 \pm 35.4^{\mathrm{a}}$ & $39.87 \pm 13.0$ & $67.45 \pm 25.1^{\mathrm{a}}$ \\
\hline r-MSSD [ms] & $14.00 \pm 10.7$ & $42.06 \pm 34.5^{\mathrm{a}}$ & $16.13 \pm 10.0$ & $56.56 \pm 36.8^{\mathrm{a}}$ \\
\hline p5ONN [\%] & $2.09 \pm 4.3$ & $11.51 \pm 12.6^{\mathrm{a}}$ & $2.17 \pm 3.4$ & $21.12 \pm 17.8^{\mathrm{a}}$ \\
\hline Trl & $28.60 \pm 15.9$ & $66.13 \pm 21.9^{\mathrm{a}}$ & $17.60 \pm 7.1$ & $42.69 \pm 22.0^{\mathrm{a}}$ \\
\hline TINN & $305.27 \pm 216.0$ & $705.75 \pm 411.4^{\mathrm{a}}$ & $158.40 \pm 74.3$ & $347.75 \pm 201.4^{\mathrm{a}}$ \\
\hline TP $\left[\mathrm{ms}^{2}\right]$ & $2054.27 \pm 1048.7$ & $5590.50 \pm 2606.6^{\mathrm{a}}$ & $2073.47 \pm 900.5$ & $6022.9^{2} \pm 2545.5^{\mathrm{a}}$ \\
\hline HF $\left[\mathrm{ms}^{2}\right]$ & $511.07 \pm 367.1$ & $1611.69 \pm 1163.4^{\mathrm{a}}$ & $615.07 \pm 390.8$ & $1879.69 \pm 1309.2^{\mathrm{a}}$ \\
\hline LF $\left[\mathrm{ms}^{2}\right]$ & $419.67 \pm 226.2$ & $1473.06 \pm 668.5^{\mathrm{a}}$ & $438.60 \pm 231.8$ & $1623.38 \pm 698.0^{\mathrm{a}}$ \\
\hline VLF $\left[\mathrm{ms}^{2}\right]$ & $590.33 \pm 283.2$ & $1437.69 \pm 466.0^{\mathrm{a}}$ & $544.33 \pm 240.9$ & $1499.25 \pm 482.8^{\mathrm{a}}$ \\
\hline ULF $\left[\mathrm{ms}^{2}\right]$ & $240.20 \pm 115.0$ & $495.63 \pm 135.9^{\mathrm{a}}$ & $173.60 \pm 74.3$ & $328.50 \pm 125.3^{\mathrm{a}}$ \\
\hline NHF & $39.93 \pm 5.5$ & $41.98 \pm 5.4$ & $43.97 \pm 7.2$ & $48.29 \pm 7.0^{0}$ \\
\hline NLF & $36.79 \pm 10.5$ & $42.51 \pm 7.8$ & $34.03 \pm 11.8$ & $40.06 \pm 9.2^{2}$ \\
\hline LF/HF & $0.94 \pm 0.3$ & $1.04 \pm 0.3$ & $0.82 \pm 0.4$ & $0.88 \pm 0.4$
\end{tabular}

aDenotes significant $(p<0.001)$ differences between cirrhotic and control group

Table III. Comparison of HRV parameters in time and frequency domain between morning activity hours and night resting hours in study and control group in 4-hour-long periods (morning activity hours 08.00-12.00; night resting hours 00.00-04.00)

Tabela III. Porównanie czasowych i częstotliwościowych parametrów HRV pomiędzy godzinami aktywności porannej (8.00-12.00) i nocnego odpoczynku (0.00-4.00) w grupie badanej i kontrolnej

\begin{tabular}{lcccc} 
Variable & \multicolumn{2}{c}{ Cirrhosis $(n=18)$} & \multicolumn{2}{c}{ Control $(n=16)$} \\
\cline { 2 - 5 } & Morning activity hours & Night resting hours & Morning activity hours & Night resting hours \\
\hline Mean NN [ms] & $680.47 \pm 108.9$ & $736.20 \pm 132.0^{\mathrm{a}}$ & $832.63 \pm 106.9$ & $1030.50 \pm 110.7^{\mathrm{a}}$ \\
\hline SDNN [ms] & $57.60 \pm 25.0$ & $44.00 \pm 15.4^{\mathrm{b}}$ & $128.88 \pm 43.9$ & $94.63 \pm 37.0^{\mathrm{a}}$ \\
\hline SDNN-ix [ms] & $21.40 \pm 8.3$ & $23.20 \pm 7.9$ & $53.13 \pm 23.6$ & $63.5 \pm 21.6^{\mathrm{a}}$ \\
\hline SDANN [ms] & $52.73 \pm 22.0$ & $39.87 \pm 13.0^{\mathrm{b}}$ & $109.25 \pm 35.4$ & $67.45 \pm 25.1^{\mathrm{a}}$ \\
\hline r-MSSD [ms] & $14.00 \pm 10.7$ & $16.13 \pm 10.0$ & $42.06 \pm 34.5$ & $56.56 \pm 36.8^{\mathrm{a}}$ \\
\hline p5ONN [\%] & $2.09 \pm 4.3$ & $2.17 \pm 3.4$ & $11.51 \pm 12.6$ & $21.12 \pm 17.8^{\mathrm{a}}$ \\
\hline Trl & $28.60 \pm 15.9$ & $17.60 \pm 7.1^{\mathrm{a}}$ & $66.13 \pm 21.9$ & $42.69 \pm 22.0^{\mathrm{a}}$ \\
\hline TINN & $305.27 \pm 216.0$ & $158.40 \pm 74.3^{\mathrm{a}}$ & $705.75 \pm 411.4$ & $347.75 \pm 201.4^{\mathrm{a}}$ \\
\hline TP $\left[\mathrm{ms}^{2}\right]$ & $2054.27 \pm 1048.7$ & $2073.47 \pm 900.5$ & $5590.50 \pm 2606.6$ & $6022.94 \pm 2545.5$ \\
\hline HF $\left[\mathrm{ms}^{2}\right]$ & $511.07 \pm 367.1$ & $615.07 \pm 390.8$ & $1611.69 \pm 1163.4$ & $1879.69 \pm 1309.2$ \\
\hline LF $\left[\mathrm{ms}^{2}\right]$ & $419.67 \pm 226.2$ & $438.60 \pm 231.8$ & $1473.06 \pm 668.5$ & $1623.38 \pm 698.0$ \\
\hline VLF $\left[\mathrm{ms}^{2}\right]$ & $590.33 \pm 283.2$ & $544.33 \pm 240.9$ & $1437.69 \pm 466.0$ & $1499.25 \pm 482.8^{\mathrm{a}}$ \\
\hline ULF $\left[\mathrm{ms}^{2}\right]$ & $240.20 \pm 115.0$ & $173.60 \pm 74.3^{\mathrm{a}}$ & $495.63 \pm 135.9$ & $328.50 \pm 125.3^{\mathrm{a}}$ \\
\hline NHF & $39.93 \pm 5.5$ & $43.97 \pm 7.2$ & $41.98 \pm 5.4$ & $48.29 \pm 7.0^{\mathrm{a}}$ \\
\hline NLF & $36.79 \pm 10.5$ & $34.03 \pm 11.8$ & $42.51 \pm 7.8$ & $40.06 \pm 9.2^{\mathrm{b}}$ \\
\hline LF/HF & $0.94 \pm 0.3$ & $0.82 \pm 0.4$ & $1.04 \pm 0.3$ & $0.88 \pm 0.4^{\mathrm{b}}$
\end{tabular}

${ }^{a}$ Denote significant $(p<0.01)$ differences between cirrhotic and control group, ${ }^{b}$ denote significant $(p<0.05)$ differences between cirrhotic and control group 
Table IV. Comparison of HRV parameters in time and frequency domain dependently on Child-Pugh classification. There were no significant differences between class A, B and C

Tabela IV. Porównanie czasowych i częstotliwościowych parametrów HRV w zależności od klasyfikacji Childa-Pugha. Nie odnotowano istotnych statystycznie różnic pomiędzy klasami A, B i C

\begin{tabular}{lccc} 
& & & Child-Pugh \\
\cline { 2 - 4 } Variable & $\mathrm{A}(n=3)$ & $\mathrm{B}(n=9)$ & $\mathrm{C}(n=6)$ \\
\hline Max HR [beats/min] & $108.00 \pm 23.81$ & $129.88 \pm 17.22$ & $127.50 \pm 16.07$ \\
\hline Min HR [beats/min] & $57.67 \pm 8.08$ & $60.5 \pm 13.49$ & $65.67 \pm 6.74$ \\
\hline Mean HR [beats/min] & $87.33 \pm 15.31$ & $85.75 \pm 18.26$ & $91.50 \pm 6.22$ \\
\hline Mean NN [ms] & $703.33 \pm 110.39$ & $702.43 \pm 132.73$ & $656.80 \pm 46.60$ \\
\hline SDNN [ms] & $52.67 \pm 10.21$ & $75.43 \pm 33.05$ & $64.00 \pm 24.61$ \\
\hline SDNN-ix [ms] & $19.00 \pm 6.56$ & $23.29 \pm 8.92$ & $21.60 \pm 4.22$ \\
\hline SDANN [ms] & $50.67 \pm 8.39$ & $68.43 \pm 28.86$ & $59.60 \pm 23.59$ \\
\hline r-MSSD [ms] & $14.00 \pm 9.00$ & $16.29 \pm 10.69$ & $15.80 \pm 9.12$ \\
\hline p5ONN [\%] & $1.13 \pm 1.51$ & $1.66 \pm 2.40$ & $2.50 \pm 3.94$ \\
\hline Trl & $29.00 \pm 5.57$ & $35.29 \pm 14.28$ & $34.60 \pm 17.64$ \\
\hline TINN & $232.00 \pm 41.73$ & $281.14 \pm 196.28$ & $300.40 \pm 133.55$ \\
\hline TP $\left[\mathrm{ms}^{2}\right]$ & $4682.33 \pm 2000.96$ & $5262.71 \pm 1700.00$ & $5659.40 \pm 1746.47$ \\
\hline HF $\left[\mathrm{ms}^{2}\right]$ & $1283.33 \pm 776.59$ & $1234.43 \pm 475.07$ & $1345.40 \pm 696.99$ \\
\hline LF $\left[\mathrm{ms}^{2}\right]$ & $941.67 \pm 534.51$ & $1123.71 \pm 621.12$ & $1063.80 \pm 321.51$ \\
\hline VLF [ms $\left.{ }^{2}\right]$ & $1154.67 \pm 468.57$ & $1558.86 \pm 690.78$ & $1549.60 \pm 522.97$ \\
\hline ULF [ms $\left.{ }^{2}\right]$ & $341 \pm 113.71$ & $530.57 \pm 221.59$ & $491.60 \pm 210.49$ \\
\hline NHF & $39.00 \pm 8.15$ & $38.24 \pm 5.02$ & $36.08 \pm 7.04$ \\
\hline NLF & $31.23 \pm 11.78$ & $33.69 \pm 10.60$ & $32.66 \pm 11.87$ \\
\hline LF/HF & $0.87 \pm 0.52$ & $0.89 \pm 0.32$ & $0.92 \pm 0.38$
\end{tabular}

night resting hours in the control group, we found significant differences in all time domain parameters and ULF, NHF, NLF and LF/HF ratio. TP, HF, LF and VLF did not differ significantly. However, in the study group we found significant differences for mean duration of NN, SDNN, SDANN, TrI, TINN and ULF. Other parameters did not differ significantly.

Another analysis was performed using the ChildPugh classification. Patients belonged to all three classes: A - 3 patients, B -9 patients, $C-6$ patients. Results are presented in Table IV. In the 24-hour period no significant differences were found in HRV parameters dependently on the Child-Pugh classification.

\section{Discussion}

Patients with liver cirrhosis, independently of aetiology, develop haemodynamic disturbances, electromechanical conjunction and autonomic nervous system and peripheral nerve disorders $[1,12,15,16]$. Autonomic nervous system disorders correlate with liver cirrhosis progression. It seems that autonomic nervous system disorder may be a worse prognostic factor in advanced stages of liver cirrhosis, including patients with cirrhotic encephalopathy $[12,17,18]$. Some authors suggest that decrease in HRV parameters is an independent mortality risk factor in patients with liver cirrhosis $[14,16]$. So far, reasons for this phenomenon are not clearly explained. It is considered that the following mechanisms are involved: autonomic neuropathy, impaired metabolism of vasoactive mediators (dopamine, norepinephrine) and lipids, and disturbed NO-mediated vasodilatation [19].

In the current study we performed an analysis of all HRV parameters in the time and frequency domain. Among HRV parameters in the time domain the most commonly used are SDNN, SDANN, r-MSSD and p50NN. Among HRV parameters in the frequency domain the most commonly used are HF, LF and HF/LH ratio. These parameters are considered to correlate with autonomic nervous function. From 24-hour record we excluded for separate analysis periods representing morning activity hours (08.00-12.00) and night resting hours (00.00-04.00). There is data on variability of HRV parameters during different hours of the day and on dis- 
turbances of HRV parameters in some diseases. Circadian rhythm of heart rate variability is a normal physiological reaction and their impairment may lead to increased of mortality [20, 21]. All HRV parameters in time domain and most of the HRV parameters in frequency domain were significantly lower in cirrhotic patients compared to control group during 24-hour observational period. LH/HF ratio and normalized HF and LF (NHF and NLF) did not differ significantly. The same differences in HRV parameters between cirrhotic patients and control group were significant for night resting hours and morning activity hours. Our results confirm previous results documented by Ates et al. [14] This study group included 30 cirrhotic patients and 28 healthy volunteers. The causes of cirrhosis were infection from hepatitis B $(n=22)$ and hepatitis C $(n=8)$. Ates et al. compared HRV parameters in time domain between cirrhotic patients and control group in 24-hour observational period. All parameters, which are given above were significantly lower in cirrhotic patients compared to control group ( $p<0.001$ ). Moreover, these parameters were significantly lower in sub-group of patients which died in 2-year observational period than in patients which survived ( $p<0.001)$. In current study we did not proved correlation between HRV parameters and grade of Child-Pugh classification, which was shown by Ates et al. Explanation for our results may be the fact, that autonomic nervous system disorders, that results in HRV disturbances, develop on very early stages of liver cirrhosis, but it seems there is no further progression in advanced stages of liver cirrhosis. It is also possible that a small number of study participants had impact on our study. Genovesi $(n=48)$ et al. [22] results confirm Ates et al. observation that decrease in HRV parameters in time domain correlate with the grade of Child-Pugh classification. Decrease in HRV parameters was associated with increase in transvenous gradient in portal blood flow and decrease in $\mathrm{Ca}^{2+}$ and total Ca concentrations. Fleisher et al. [16] found significantly lower pNN50 (p50NN) parameters and estimated entropy (non-linear HRV parameter) in cirrhotic patients waiting for liver transplantation compared to healthy controls. Mani et al. [13] documented significant reduction of SDNN, LH and HF in cirrhotic subjects $(n=80)$ with encephalopathy compared to healthy volunteers $(n=11)$; significant differences were not found for $\mathrm{LH} / \mathrm{HF}$ ratio. Our results confirm the findings of Mani et al. However, Mani et al. proved that HRV parameter disturbances correlate with liver cirrhosis progression estimated by the Child-Pugh scoring system, which was not documented in our studies. The results of Keresztes et al. [15] indicated that HRV parameters in the time and frequency domain (SDNN, r-MSSD, pNN50, TP, LF, HF) are significantly lower in cirrhotic patients compared to healthy controls. Contrary to our results Keresztes et al. did not find significant differences in SDANN. Because SDANN reflects sympathetic nervous system function this may indicate sympathetic nervous system activation. Keresztes et al. speculate that reduction in HRV parameters is a consequence of both autonomic nervous system disorder and peripheral sensory nerve disturbances. Newton et al. [12] indicated that frequency HRV parameters are significantly reduced in patients with liver cirrhosis. Milovanovic et al. [23] revealed that both short-term and 24-hour HRV parameters are disturbed in patients $(n=16)$ with alcoholic liver cirrhosis compared to healthy volunteers $(n=19)$. This group had significantly depressed SDNN, SDANN, Trl, LF and HF values. The authors did not find differences in mean NN, r-MSSD, and LF/HF ratio. These results are comparable with our result in which only r-MSSD differed between study and control groups. Milovanovic et al. suggest a decreased SDNN value as a potential risk predictor of sudden cardiac death. Iga et al. [6] reported that HRV abnormalities appear in early stages of liver cirrhosis and depend on changes of norepinephrine level.

Circadian variation of HRV parameters is reported by some authors. This phenomenon was observed in healthy subjects. In elderly patients circadian HRV variation is disturbed for example in arterial hypertension (HA) or diabetes mellitus (DM) [20, 24, 25].

Circadian variation of HRV parameters in healthy subjects was confirmed in the current study. We proved that all time parameters and ULF, NHF, NLF and LF/HF ratio values calculated separately in night resting hours and morning activity hours differed significantly in healthy controls. In cirrhotic patients we did not observe circadian variability of the parameters r-MSSD, pNN50, NHF, NLF and LF/HF, but we noted circadian variation in mean NN, SDNN, SDANN, Trl, TINN and ULF.

Decrease in circadian HRV variation in cirrhotic patients reflects autonomic nervous system regulation disorders. Perciaccante et al. [26] suggest that resistance to insulin that is observed in many pathological conditions may have a role in decrease in circadian variation of HRV parameters. These disturbances seem to be irreversible although patients undergo treatment. Kołasińska-Kloch et al. [20] indicated that in hypertensive patients disturbed circadian variation of HRV parameters had not been normalized even though patients were treated effectively with ACE-I (enalapril). We are in need of further studies.

\section{Conclusions}

The current work has proven that patients with liver cirrhosis have significantly lower HRV parameters than healthy subjects. It has been demonstrated for all HRV 
parameters in the time domain and most HRV parameters in the frequency domain. Heart rate variability correlation with liver cirrhosis progression (Child-Pugh classification) has not been observed. In liver cirrhosis not only are HRV parameters affected but also circadian variation of HRV is disturbed. It seems that these HRV disturbances appear in early stages of liver cirrhosis and are stable even though liver cirrhosis develops. Other study groups have documented that decreases in HRV parameters correlate with progression of liver cirrhosis. It is possible that the small number of study participants affected our results, but it is also possible that an undiscovered factor plays a role.

Limitations of the current study were the small number of participants and the specific group of them. The presented work is only preliminary. Currently, the studied group has a lot more persons. We are also performing serial measurements of HRV parameters in the same patients. A group with compensated cirrhosis was also included. In our opinion the presented problem requires further research and inquiry.

\section{Acknowledgments}

Jolanta Białkowska and Adam Rafał Poliwczak contributed equally to this paper.

\section{References}

1. Wong F. Cirrhotic cardiomyopathy. Hepatol Int 2009; 3: 294-304.

2. Möller S, Henriksen JH. Cardiovascular complications of cirrhosis. Gut 2008; 28: 59-69.

3. Baik SK, Lee SS. Cirrhotic cardiomyopathy. Orphanet encyclopedia, January 2005. http://www.orpha.net/data/patho/GB/ uk-CirrhoticCardiomyopathy.pdf

4. Hamoudi WA, Lee SS. Cirrhotic cardiomyopathy. Ann Hepatol 2006; 5: 132-9.

5. Frøkjaer VG, Strauss GI, Mehelsen J, et al. Autonomic dysfunction and impaired cerebral autoregulation in cirrhosis. Clin Auton Res 2006; 16: 208-16.

6. Iga A, Nomura M, Sawada $Y$, et al. Autonomic nervous dysfunction In patients with liver cirrhosis using 123I-metaiodobenzylguanide myocardial scintigraphy and spectrum analysis of heart-rate variability. J Gastroenterol Hepatol 2003; 18: 651-9.

7. Task Force of the European Society of Cardiology and North American Society of Pacing and Electrophisiology. Heart rate variability: standards of measurement, physiological interpretation and clinical use. Circulation 1996; 93: 1043-65.

8. Wichterle D, Simek J, La Rovere MT, et al. Prevalent low-frequency oscillation of heart rate. Nove predictor of mortality after myocardial infarction. Circulation 2004; 110: 1183-90.

9. Acharya UR, Joseph KP, Kannathal N, et al. Heart rate variability: a review. Med Bio Eng Comput 2006; 44: 1031-51.

10. Pal GK, Pal P, Nanda N, et al. Spectral analysis of heart rate variability (HRV) may predict the future development of essential hypertension. Med Hypotheses 2009; 72: 183-5.
11. Wachowiak-Baszyńska $\mathrm{H}$, Ochotny $\mathrm{R}$. Heart rate variability in ischemic heart disease. Part III: Correlates of heart rate variability parameters and the severity of coronary atherosclerosis and left ventricular function in patients with stable ischemic heart disease. Folia Cardiologica 2001; 8: 355-61.

12. Newton JL, Allen J, Kerr S, Jones DEJ. Reduced heart rate variability and baroreflex sensitivity in praimary biliary cirrhosis. Liver Int 2006; 26: 197-202.

13. Mani AR, Montagnese S, Jackson CD, et al. Decreased heart rate variability in patients with cirrhosis relates to the presence and degree of hepatic encephalopathy. Am J Physiol Gastrointest Liver Physiol 2009; 296: G330-8.

14. Ates F, Topal E, Kosar F, et al. The relationship of heart rate variability with severity and prognosis of cirrhosis. Dig Dis Sci 2006; 51: 1614-8

15. Keresztes K, Istenes I, Folhoffner A, et al. Autonomic and sensory nerve dysfunction in primary biliary cirrhosis. World J Gastroenterol 2004; 10: 3039-43.

16. Fleisher LA, Fleckenstein JF, Frank SM, et al. Heart rate variability as a predictor of autonomic dysfunction in patients awaiting liver transplantation. Dig Dis Sci 200; 45: 340-4.

17. Fleckenstein JF, Frank SM, Thuluvath PJ. Presence of autonomic neuropathy is a poor prognostic indicator in patients with advanced liver disease. Hepatology 1996; 23: 471-5.

18. Hendrickse MT, Triger DR. Autonomic dysfunction in chronic liver disease. Clin Autonom Res 1993; 3: 227-31.

19. Campillo B, Chabrier PE, Pelle G, et al. Inhibition of nitric oxide synthesis in the forearm arterial bed of patients with advanced cirrhosis. Hepatology 1995; 22: 1423-9.

20. Kołasińska-Kloch W, Furgała A, Banach T, et al. Circadian heart rate variability in patients with primary arterial hypertension. Przegl Lek 2002; 59: 752-5.

21. Massin MM, Maeyns K, Withofs N, et al. Circadian rhythm of heart rate and heart rate variability. Arch Dis Child 200; 83: 179-82.

22. Genovesi S, Prata-Pizzala DM, Pozzi M, et al. QT interval prolongation and decreased heart rate variability in cirrhotic patients: revelance of hepatic venous pressure gradient and serum calcium. Clin Sci 2009; 116: 851-9.

23. Milovanovic B, Milinic N, Trifunovic D, et al. Autonomic dysfunction in alcoholic cirrhosis and its relation to sudden cardiac death risk predictors. Gen Physiol Biophys 2009; Special Issue 28: 251-61.

24. Kardelen F, Akcurin G, Ertug $\mathrm{H}$, et al. Heart rate variability and circadian variations in type 1 diabetes mellitus. Pediatr Diabetes 2006; 7: 45-50.

25. Bonnemeier H, Richardt G, Potratz J, et al. Circadian profile of cardiac autonomic nervous modulation in healthy subjects: differing effects of aging and gender on heart rate variability. J Cardiovasc Electrophysiol 2003; 14: 800-2.

26. Perciaccante A, Fiorentini A, Paris A, et al. Circadian rhythm of the autonomic nervous system in insulin resistant subjects with normoglycemia, impaired fasting glycemia, impaired glucose tolerance, type 2 diabetes mellitus. BMC Cardiovascr Disord 2006; 6: 19-28. 